Open Access

Research Article
Res. Agric. Livest. Fish. Vol. 2, No. 1, April 2015: 125-133

\title{
FISHERS ACCESS TO THE COMMON PROPERTY WATERBODIES IN THE NORTHERN REGION OF BANGLADESH
}

\author{
Md. Amzad Hossain ${ }^{1 *}$, Mousumi Das ${ }^{1}$, Md. Shahanoor Alam² and Md. Enamul Haque ${ }^{3}$ \\ ${ }^{1}$ Department of Aquaculture, Bangabandhu Sheikh Mujibur Rahman Agricultural University \\ (BSMRAU), Gazipur-1706, Bangladesh; 'Department of Genetics and Fish Breeding, BSMRAU, \\ Gazipur-1706, Bangladesh; ${ }^{3}$ Department of Agriculture Extension and Rural development, \\ BSMRAU, Gazipur-1706, Bangladesh
}

*Corresponding author: Md. Amzad Hossain; E-mail: amzad@bsmrau.edu.bd

\section{ARTICLE INFO ABSTRACT}

\begin{abstract}
Received
17.03.2015

Accepted

12.04.2015

Online

19.04.2015

Key words

Fishers

Access

Common property

waterbody

Biodiversity

The study was designed to explore the status of fishers' access to the common property waterbodies (CPW) and associated problems of using CPW. Three upazillas (administrative units) of the Northern region of Bangladesh were selected for the empirical study. Data were collected from fishers, non-fishers and other stakeholders through structured interview schedules, physical observation, and participatory rural appraisal (PRA). The access of poor fishers group to the CPW was very limited in the study area. The government policy of revenue collection through leasing system badly affected the fishers group as they do not have required level of capital, unity, leadership and education. A revenue oriented fisheries management system with short lease periods was found to encourage over-fishing and destructive fishing by lessees, where the lessees were noted to sweep away all the fish stock as soon as their contract ended without considering the sustainable use of resource and biodiversity. Consequently, the productivity of the CPW is declining gradually. To ensure the effective access of fishers' group to CPW and their sustainable use, an advised long-term community based management (CBM) plan needs to be developed with the effective participation of the fishers' groups and other stakeholders.
\end{abstract}

To cite this article: MA Hossain, M Das, MS Alam and ME Haque. 2015. Fishers access to the common property waterbodies in the Northern region of Bangladesh. Res. Agric. Livest. Fish. 2 (1): 125-133. 


\section{INTRODUCTION}

Fisheries are important sub-sector of agriculture in Bangladesh and play a significant role in nutrition, employment, foreign exchange earnings and food supply (Dey et al., 2005; Roos et al., 2007). The fishery subsector contributed $4.37 \%$ to GDP at current price during 2012-13. Around 16.2 million people earn their livelihood directly or indirectly from activities related to fisheries (DoF, 2014). Total fish production in 2012-2013 was 3.41 million Metric Tons (MT) of which 2.82 million MT came from inland waterbodies and 0.59 million MT from marine fisheries (FRSS, 2014).

Historically, most of inland waterbodies were non-private or state property where fishing, animal grazing, fodder and plant harvesting were open to all. Those waterbodies are known as common property waterbodies (CPW). In course of time the government took away free fishing rights from the relatively large waterbodies (e.g., rivers, beels and haors) through establishment of periodic leasing system in order to generate revenues (Toufique, 1999). To facilitate the leasing process rivers and their tributaries are divided by the Ministry of Land (MoL) into several small arbitrary segments. These segments or waterbodies are then leased out through auction for the collection of revenue. Similarly, beels (land depressions) and ponds owned by the government fall under this category. There are over 10,000 waterbodies (inland waterbodies generating government revenue) in Bangladesh (Viswanathan et al., 2002) and they are leased to the highest bidder with a preference for fisher cooperatives but very often, either directly or by bidding through a cooperative, control ends in the hands of the rich and influential lessees. Due to the private auction leasing system, fishers' access to inland fisheries has become increasingly difficult and competition over the fisheries resources is becoming more intense and complex every year. This leasing system created a group of middle agents, usually from rich and elite class, who with their economic and social powers, established perpetual authority over these resources and continued to be benefited at the expense of the professional and hereditary fishers (Khan, 2012).

Over the years, introduction of new agricultural technologies and increased competitive pressures for more intensive use of the wetlands resulted in the deterioration of fisheries resources as well as reduced the size of CPW. Nevertheless, traditional rules of fishing rights by the community were maintained, at least in the water areas with marginal or no use value for agricultural purposes. Development policies with respect to these water resources seldom consider the interests of the poor communities who used to derive benefits for their livelihood (Ahmed, 1993).

In the above context, it is evident that the present status of CPW in economically deprived areas, their access to poor fishers' community and most importantly their management strategy need to be clarified to satisfy their sustainable use. Therefore, in this study a pragmatic approach was undertaken to explore the empirical picture of fishers' access to the CPW and their provident consequences in adversely poverty affected Northern region of Bangladesh.

\section{MATERIALS AND METHODS}

\section{Study area and sampling frame}

In the present study government owned waterbodies, which can be accessed or should be accessed by common people free of cost or on lease basis, are considered as CPW (river, flood plain, beel, pond etc.). Data were collected from villages adjacent to the selected CPW under three upazillas (administrative unit) of the northern region of Bangladesh (Fig.1). Details of the sampling design are shown in Table 1.

Table 1. Details of the sampling design

\begin{tabular}{|c|c|c|c|c|c|}
\hline District & Upazilla & Selected CPW & Village & $\begin{array}{c}\text { Fisher } \\
\text { respondent }\end{array}$ & $\begin{array}{l}\text { Non-Fisher } \\
\text { responden }\end{array}$ \\
\hline Lalmonirhat & $\begin{array}{l}\text { Lalmonirhat } \\
\text { sadar }\end{array}$ & Ratnai Nodi & Kulaghat, Khatamari & 106 & 51 \\
\hline Kurigram & Kurigram sadar & Dasherhat Charra & Polasbari, Cherenga & 95 & 71 \\
\hline \multirow[t]{2}{*}{ Rangpur } & Pirgaccha & Masankura Moranodi & Nijpara, Kabila para & 73 & 56 \\
\hline & & Total & & 274 & 178 \\
\hline
\end{tabular}




\section{Data collection methods}

The study was conducted through Participatory Rural Appraisal (PRA), survey, monitoring, discussion and consultation among the resource users and stakeholders. Two interview schedules were used for data collection. One was for fishers, non-fishers, and another for different stakeholders including upazilla and district level Personnel of MoL, Department of Fisheries and Ministry of Youth and Sports. Fishers and nonfishers in the study area were selected through simple random sampling method. Fishermen were interviewed at home and or fishing sites. In a given day approximately five to seven interviews were conducted where each interview schedule for fishermen was addressed the issue of fishing activities, access to CPW and their problems relating to access.

PRA tool such as focus group discussion (FGD) was done with fisher and non-fisher groups in the study areas. Nine FGD sessions, three from each location, were conducted, where each group had 10 to 14 people. FGD sessions were held in front of village shops and on the bank of CPW. Secondary data were collected from relevant upazilla and district level Govt. offices, statistical yearbook, project reports, scientific articles and websites.

\section{Data processing and analysis}

Data from various sources were coded and entered into database system using Microsoft excel and analyzed though simple statistical methods.

\section{RESULTS}

\section{Present status of CPW in the study areas}

The present status of CPW of three upazillas is presented in Table 2. Data show that most of the waterbodies were leased out to the cooperative in Pirgacha upazilla where in most cases the lessees were nonfishers. In Lalmonirhat and Kurigram sadar the huge percentage of non-leased waterbodies were comprised with river where leasing was unmanageable. Production performance of CPW was about two third in Lalmonirhat sadar comparing with other two upazillas.

\section{Leasing system of CPW}

Government declared the pro-fishers oriented Jolmohal Policies restrict the lease of CPW within fishers. If an organization of real fishers is registered with cooperative department or department of social welfare at local level then it will be qualified to participate in the lease process. But if the organization has any non-fisher member then it would not be qualified to get the Jolmohal settlement. Individual person or unregistered Community Based Organization (CBO) does not qualify to apply for CPW. Some important features of the new policy are shown in Table 3.

\section{Access to CPW}

Fishers always did not get access to adjacent waterbodies. Most of the fisher had access to non-leased waterbodies (river and flood plain), which was about $94.5 \%$ of the total fisher, followed by beel (Fig. 2). They had access to ponds, small ditches, canals and irrigation canals in small scales. When access to the nearest waterbodies becomes restricted due to lease out or Govt. ban, the fishers have no way but to move to other open waterbodies which often far away from their locality. However, as the non-fishers and subsistence fishers do not depend on the fish catch for their livelihood, they do not go over long distance. The professional fishers go for fishing in different seasonal waterbodies. In the wet season when some low agricultural land is inundated by water they turn into seasonal fishing grounds.

These temporary fishing grounds are lost when Aman rice cultivation resumes. They exist for three to four months: from the middle of June to the middle of October. But increasingly the owners of the land where these seasonal fishing grounds are formed do not allow the fishers to fish. Some of them have started to charge a fee for access rights while others are having fish aquaculture there by themselves. The professional fishers also fish in the river for two months during March and April. In other season they are hired on contract basis for harvesting fish from the ponds during dry season. Search costs are high, as they have to move from one waterbody to another on foot. A large part of their time is spent on travelling to these marginal waterbodies. As less time available for actual fishing their income fall significantly. This exodus of the fishers to the marginal fishing grounds prompted the landowners to impose new conditions for fishing. Fishers now have to pay more for access rights to these fishing grounds. 
Table 2. Present status of CPW in the study areas

\begin{tabular}{|lccc|}
\hline & \multicolumn{3}{c|}{ Name of Upazilla } \\
\cline { 2 - 4 } Total area of CPW (ha) & Pirgacha & Lalmonirhat sadar & Kurigram sadar \\
& 71.51 & 282.84 & 12423.90 \\
$\%$ Leased area & & & 1.47 \\
$\%$ Not leased area & 98.07 & 13.58 & 98.53 \\
Production rate of CPW $\left(\mathrm{kg} \mathrm{ha}^{-1}\right.$ year $\left.^{-1}\right)$ & 1.93 & 86.42 & 395.80 \\
\hline
\end{tabular}

Table 3. Government Jolmohal Policy 2009

\begin{tabular}{|c|c|c|c|}
\hline \multirow[t]{2}{*}{ Criteria } & \multicolumn{2}{|c|}{ Type of Jolmohal } & \multirow[t]{2}{*}{ Remarks } \\
\hline & CPW over 20 acres & CPW below 20 acres & \\
\hline Eligibility & $\begin{array}{l}\text { Registered Community Based } \\
\text { Organization (CBO) }\end{array}$ & Registered CBO & $\begin{array}{l}\text { All members must } \\
\text { be fishers }\end{array}$ \\
\hline Leasing & District Jolmohal Management & Upazila Jolmohal Management & In absence of $A C$ \\
\hline authority & $\begin{array}{l}\text { Committee on behalf of MoL (DC } \\
\text { convener, RDC } \\
2\end{array}$ & $\begin{array}{l}\text { Committee } \mathrm{MoL}\left(\mathrm{UNO}^{3} \text { convener, }\right. \\
\mathrm{AC}^{4} \text { Land Member Secretary) }\end{array}$ & $\begin{array}{l}\text { (Land) upazilla } \\
\text { cooperative officer }\end{array}$ \\
\hline $\begin{array}{l}\text { Lease } \\
\text { period }\end{array}$ & Max. 3 years & Max. 3 years & \\
\hline $\begin{array}{l}\text { Lease } \\
\text { value }\end{array}$ & Average of last 3 years plus $5 \%$ & Average of last 3 years plus $5 \%$ & \\
\hline Access & $\begin{array}{l}\text { No CBO will get tenure of more than } \\
\text { two Jolmohals }\end{array}$ & $\begin{array}{l}\text { No CBO will get tenure of more than } \\
\text { two Jolmohals }\end{array}$ & \\
\hline
\end{tabular}

${ }^{1}$ District Commissioner; ${ }^{2}$ Revenue Deputy Commissioner; ${ }^{3}$ Upazila Nirbahi Officer; ${ }^{4}$ Assistant Commissioner

Table 4. Problems of using CPW

$\begin{array}{lc}\text { Problem } & \text { Rank } \\ \text { Decrease in catch from open waters } & 1 \\ \text { Short tenure of lease } & 2 \\ \text { Development of culture based fisheries in private owned seasonal flood plain } & 3 \\ \text { Control of CPW by influential person } & 4 \\ \text { Lack of alternative job in ban or lean period } & 5 \\ \text { Difficulty in forming CBO } & 6 \\ \text { Shortage of lease money } & 7 \\ \text { High lease value } & 8 \\ \text { Limited contact with concerned Govt. Official } & 9 \\ \text { Social conflict } & 10\end{array}$

\section{Mode of involvement in fishing}

Among the fishers, $85.0 \%$ were professional, they completely depend on fish capture and selling for their livelihood (Fig. 3) while 12\% and rest were seasonal and subsistence respectively. The seasonal fishers generally caught fish only in the peak season of fishing but in the lean fishing season they had to find out alternative way for livelihood, as the return from fishing was very poor to ensure their living. On the other hand, majorityof non-fishers (96\%) used to catch fish from CPW only for their own consumption.

\section{Problems of using CPW}

Respondents were asked about the problems of using CPW and the responses were ranked according to the prioritization (Table 4). 


\section{DISCUSSION}

In the present study, 'Fisher' is considered as someone who catches fish from natural source and sells it for the livelihood. All others rural people who do not fish for their business purpose but may occasionally catch fish for their own consumption are grouped as non-fisher. There are several groups involved in fishing or fishing related activities in inland open waters of Bangladesh and they include the traditional caste fishers (mostly Hindus), non-traditional fishers (who entered fishing later), the leaseholders of waterbodies (who are mostly non-fishers), and the general fishers (members of the public) (Blanchet, 1993).

The present access status and leasing system of CPW has created substantive problems for the fishers group as well as the whole community. Decrease of fish catch from open water was the most mentioned problem by the fishers. In the past, waterbodies were full of fish. However, availability of fish has declined in the recent time. Open access to the non-leased waterbodies was the main cause for dwindling fish stock and bio-diversity. Fishers always do not follow fishing regulation and indiscriminately harvest small fish and brood fish where they have full access.

On the other hand, in case of lease out waterbodies the present Jolmohal Policy allows three years of lease period while the bureaucratic systems may take time and make the lease period even shorter. When a lessee takes lease of a waterbody for short time, he cannot contribute to improve the habitat and fish stock. On the contrary, he exploits heavily by harvesting fry, brood fishes and draining up the fish pocket or shelter in dry season before ending his tenure. Khaled (1985) examined leasing methods of river fisheries and found that overexploitation of the fisheries is encouraged by the government through its existing leasing system. Under this system leaseholders receive short-term leases with no guarantee that a lessee will be able to renew the lease of the same fishery in successive years. Barr and Dixon's (2001) studied on the management of CPR in Bangladesh and revealed that a revenue oriented fisheries management system with short lease terms where lease values increase yearly with no consideration for the productivity of waterbodies encourages over fishing and destructive fishing. The lessees most often dewater waterbodies to maximize profit at the expense of the sustainability of fish biodiversity.

Similarly, the difficulty in establishing user rights when combined with the disincentive effect of short-term leases, further reduces the return from stocking or semi-intensive aquaculture in CPW. When lake fishing shifts from capture to semi-intensive (stocking, without fertilizer use) or intensive (stocking with fertilizer use) some infrastructures are needed. Landing platforms are needed with connections to the main roads connecting to the markets, to be able to carry at a reasonable cost the high volume of fish to the market. Govt. has leased out the CPW for better management and revenue collection. However, the poor fishers' community cannot often arrange lease money and lose the control over CPW.

Recent expansion of aquaculture has reduced the access of the poor to CPW. However, when the floodplain aquaculture is conducted in private land, the landowner can only be a member. In case of Govt. land the people who can subscribe can take part in the process of fish culture. Blanchet (1993) in her study of Shanir Haor in the wetland region of Bangladesh showed how property rights, fishers access to fisheries and local fishing practices differ from the text of the law. The powerful leaseholders of water estates claim ownership over the fish stock at all times of the year. Lack of alternative job in ban or lean period of the year was another problem faced by the fishers in the study areas. When CBO adopt restrictions on fishing during the spawning season or ban on fine mesh nets, this is likely to reduce the income of fishers who depend day to day on fishing for their livelihood.

In the study area most of the respondents emphasized on the community based approach to get access to CPW and sustainable management. However, they found establishment of CBO was very difficult. This is due to lack of capital, education and integrity where influential member of the CBO often exploits them. Sometimes $\mathrm{CBO}$ leaders work for the interest of outsiders influential non-fishers. There were several initiatives in the country for community based management of CPW including Community Based Fisheries Management Project -1 (CBFM-1) and CBFM-2. It was found that most of the CBO formed by them worked effectively during the project period when the project gives support to the $\mathrm{CBO}$. After completion of project period $\mathrm{CBO}$ do not work properly. 


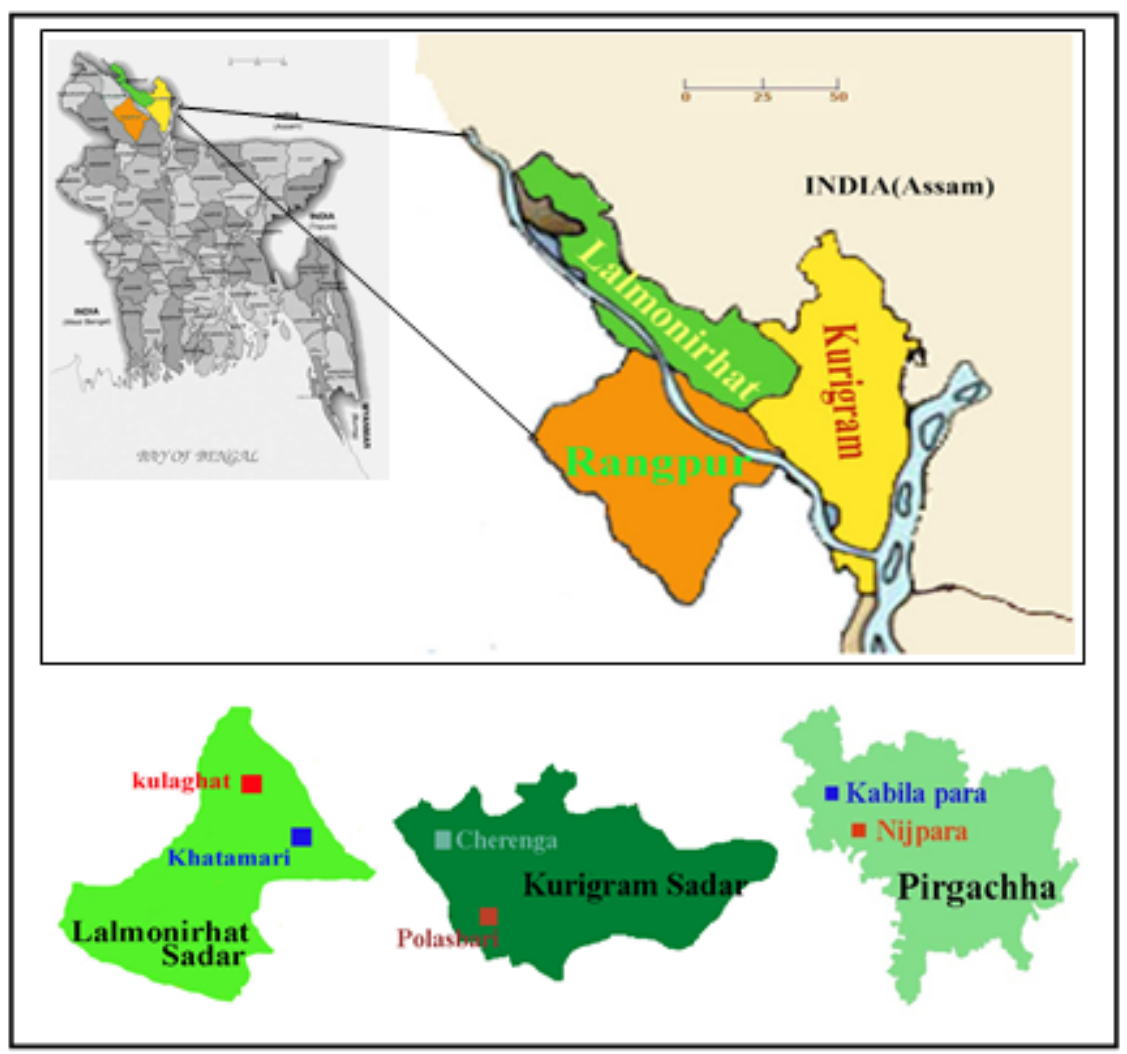

Figure 1. Map of the study area showing northern districts (sampled villages with legend)

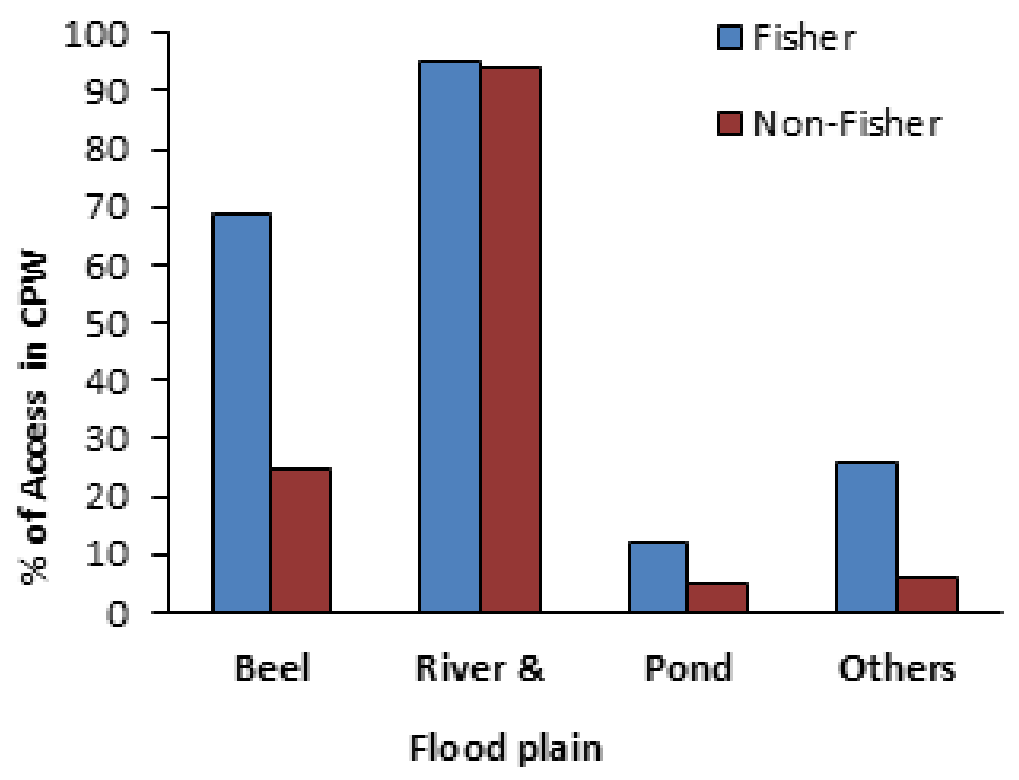

Figure 2. Present access status of CPW of fisher and non-fisher group $(n=452)$ 


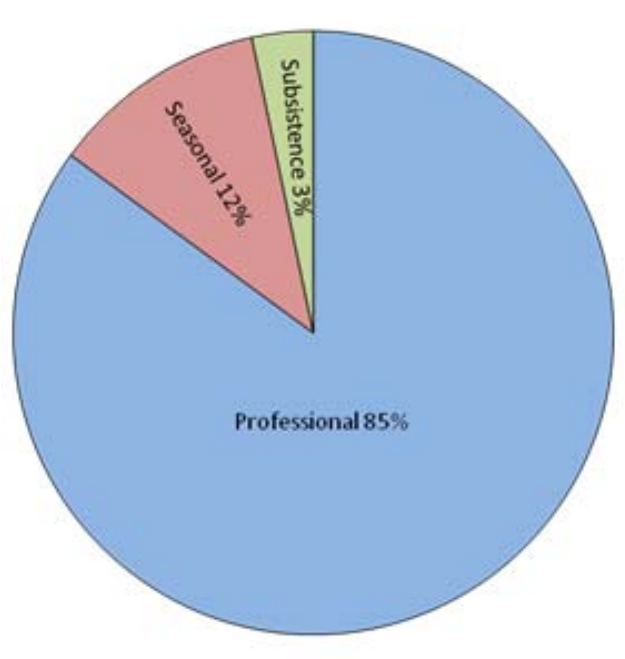

Fisher

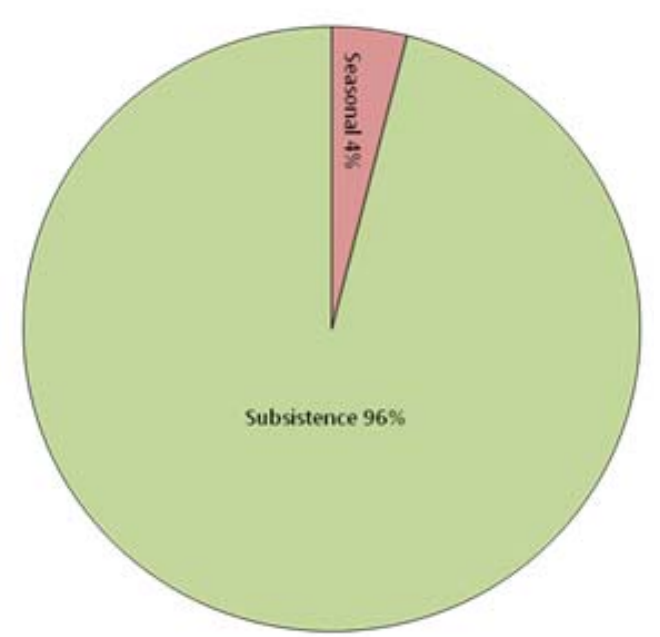

Non-fisher

Figure 3. Mode of involvement in fishing in CPW by fishers $(n=274)$ and non-fishers $(n=178)$

Access of fishers to CPW can be sustained through CBFM approach. CBFM controls the resource with the involvement of some government or other non-government organizations (NGO), at least for a certain period. The coastal marine fisheries resources management in Fiji, Solomon Island (Baines, 1989), coastal Japan (Ruddle, 1989), Java/Indonesia, West Africa (Lasserre and Ruddle, 1983), Mali (Moorehead, 1989) and Hawaii (Costa-Pierce, 1987; Berkes, 1996) has been shown to be successful through CBO. The Maine lobster fishery is an example of both communal and state property, where fishermen use it as a communal resource but the state maintains some management jurisdiction (Acheson, 1989). Experiences of the last decades have indicated that initiatives to alleviate poverty and achieve food security can seldom be preserved if planned without the involvement of the community. Community-centred approaches (CCA) encourage self-reliance, self-help and by doing so, raise self-esteem. Such approaches aim at empowering communities to make optimal use of locally available resources, and to effectively demand additional resources and better services to improve their livelihoods. Building on traditional social networks of support and mutual assistance, CCA mobilize community members in activities to meet their perceived needs and development priorities, thus making a significant contribution to sustainable development at local and national levels. CCA help to ensure that a range of stakeholders including women and marginal groups becomes part of the development process, real issues and needs are addressed, implementation and monitoring are improved, and sustainability enhances by giving users the leading role in developing and adapting activities. To reduce the risk of low compliance or seasonal loss of fishing incomes, Govt., local NGO should identify potentially profitable income generating activities that can compensate for restrictions on fishing and provide micro-credit and training in these activities to groups of poor fishers.

In Japan, the fishers' organization provide fund to Govt. mariculture corporations to stock coastal area with hatchery-produced fry. The fishers stop total harvesting from the stocked area or stop harvesting of the particular species for a certain period. After the self-imposed ban period they get a handsome harvest (Ruddle, 1989). This technique could be a good exemplary to manage the sustainable access of the fishers' to CPW.

\section{CONCLUSION}

Fishers could not benefit from Government policy regarding CPW and the new policy could not ensure leasing access due to lack of education, capital, unity, and leadership. In the present situation of Bangladesh complete open access to CPW was found unproductive. In open access system, fish stock declined drastically due to illegal and over fishing. Moreover, the current leasing system was found ineffective. Leasing of CPW should primarily be a means of controlling access to waterbodies to ensure sustainable management and not a 
system to raise government revenue. All management of CPW must be subjected to the preparation and implementation of a regulatory plan with the participation of fisher and user communities through CBM strategies. However, if the CPW properly utilized by the poor fisher it may contribute significantly to their income generation and nutrition security, thus will help to ensure food security of extremely poverty affected areas at the Northern region of Bangladesh.

\section{ACKNOWLEDGMENTS}

This study was financed under the Research Grants Scheme (RGS) of the National Food Policy Capacity Strengthening Programme (NFPCSP). The NFPCSP is implemented by the Food and Agriculture Organization (FAO) of the United Nations (UN) the Food Planning and Monitoring Unit (FPMU and Ministry of Food and Disaster Management with the financial support of European Union (EU) and USAID.

\section{REFERENCES}

1. Acheson JM, 1989. Where have all the exploiters gone? Co-management of the Maine Lobster industry. In Common property resource: ecology and community-based sustainable development, Eds., Berkes, F. Belhaven Press, London, pp: 199-217.

2. Ahmed M, 1993. Rights, Benefits and Social Justice: Keeping Common Property Freshwater Wetland Ecosystem of Bangladesh Common. Paper presented at the Fourth Common Property Conference, ICLARM, Philippines.

3. Baines GBK, 1989. Traditional resource management in the Melanesian South Pacific: a development dilemma. In Common property resources: ecology and community based sustainable development, Eds., Berkes, F. Belhaven Press, London, pp: 273-295.

4. Barr JJF and PJ Dixon, 2001. Methods for consensus building for management of common property resources. Final Technical Report for project R7562. London: DFID.

5. Berkes F, 1996. Social Systems, Ecological Systems and Property Rights. In Ecological, Economic, Cultural, and Political Principles of Institutions for the Environment, Eds., Hanna, SS, C, Folke and KG, Maler. Island Press, Washington, DC, pp: 87-107.

6. Blanchet T, 1993. Fisheries specialist study: draft final. FAP 6. Dhaka: Northeast Regional Water Management Project, CIDA with the Government of Bangladesh.

7. Costa-Pierce BA, 1987. Aquaculture in ancient Hawaii, Bioscience, 37: 320-330.

8. Dey MM, MA Rab, A Kumar, A Nisapa and M Ahmed, 2005. Food safety standard and regulatory measures: Implications for selected fish exporting Asian countries, Aquaculture Economics and Management, 9 (1\&2): 217-236.

9. DoF (Department of Fisheries), 2014. Saranica, Matsya Pakhya Sankalan, Ministry of Fisheries and Livestock. The Government of Peoples republic of Bangladesh, Dhaka, Bangladesh. pp. 124.

10. FRSS, 2014. Fisheries Statistical Year Book. Fisheries Resources Survey Systems. Department of Fisheries, Ministry of Fisheries and Livestock, Dhaka, Bangladesh. pp. 50.

11. Hardin G, 1998. "Extensions of 'The tragedy of the commons'". Science, 280 (5364): 682-683.

12. Khaled MS, 1985. Production technology of the riverine fisheries in Bangladesh. In Small-scale fisheries in Asia: socio-economic analysis and policy, Eds., Theodore, P. International Development Research Centre, Canada.

13. Khan MA, MF Alam and KJ Islam, 2012. The impact of co-management on household income and expenditure: An empirical analysis of common property fishery resource management in Bangladesh. Ocean \& Coastal Management, 65: 67-78.

14. Lasserre $\mathrm{D}$ and $\mathrm{K}$ Ruddle, 1983. Traditional knowledge and management of marine coastal systems. Biology International Special Issue 4.

15. Moorehead R, 1989. Changes taking places in common property resource management in the Inland Niger Delta of Mali. In Common property resources: ecology and community based sustainable development, Eds., Berkes, F. Belhaven Press, London. pp. 256-272.

16. Roos N, AM Wahab, C Chamnan and SH, Thilsted, 2007. The role of fish in food-based strategies to combat vitamin A and mineral deficiencies in developing countries. Journal of Nutrition, 137: 11061109. 
17. Ruddle K, 1989. Solving the common-property dilemma: village fisheries rights in Japanese coastal waters. In Common property resources: ecology and community based sustainable development, Eds., Berkes, F. Belhaven Press, London. pp. 168-184.

18. Toufique KA, 1999. Property rights and power structure in inland fisheries in Bangladesh. In Sustainable inland fisheries management in Bangladesh, Eds., Middendorp, HAJ. PM. Thompson and RS. Pomeroy. ICLARM, Manila, pp. 57-63.

19. Viswanathan KK, A Mahfuzuddin, $P$ Thompson, $P$ Sultana, M Dey and M Torell, 2002. ICLARM-The World Fish Centres Experience with Social Research on Governance and Collective Action in Aquatic Resources, Paper presented for the conference on the Role of Social Research in CGIAR . Supporting the strategy-Achieving Development Impact, 11-14 September 2002, CIAT, Cali, Columbia. 